\title{
Users' attitude towards telecommunication operators: a Study on Grameenphone and Banglalink
}

\author{
S. M. Sohel Ahmed \\ Lecturer, Department of Marketing \\ Lalmatia Mohila (Girls') College (National University) \\ Lalmatia, Mohammadpur, Dhaka, Bangladesh.
}

\begin{abstract}
Attitude is the amount of affect or feelings for or against stimulus. This study adopts with descriptive in nature. Main objective of the study is to find out users' attitude towards telecommunication operators. Fishbeins multi-attribute model was used to measure the attitude of users of Grameenphone and Banglalink.64 salient beliefs were identified but respondents are awarded about eighteen salient beliefs. Those are network facility, SMS services, 3 g services, internet modem, sports news, health line, face book services, call block, F\& F services, Balance transfer, conference call, emergency balance, ring tone, internet services, promotional offer, welcome tune, availability of services and SMS alert. The users of Grameenphone has greater positive attitude than the users of Banglalink.
\end{abstract}

Keywords: Attitude, Belief, Telecommunication, Grameenphone, Banglalink

\section{INTRODUCTION}

Attitude is predisposition or a tendency to respond to positively or negatively towards a certain idea, object, person or situation (http:/www.businessdictionary.com/definition/attitude.html). Citycell is the first mobile phone operator in Bangladesh. Thereafter, Grameenphone (market leader in Bangladesh), Banglalink, Robi, Teletalk, and Airtel entered into the telecom industry in Bangladesh. Now the total numbers of mobile phone users are 150.945 millions in Bangladesh (BTRC, June, 2018).The government of Bangladesh has identified ICT as one of the thrust sectors for rapid economic development, unemployment, \& poverty alleviation (The Daily Star, 09.02.2011). In recent years, mobile communications are experiencing higher growth rates in low income countries. For instance, during 1995-1998, mobile subscribers in low income countries registered an annual percentage growth rate of $117 \%$ compared to rate of $47 \%$ for high income countries during the same period (ITU). The wider acceptance \& adoption of digital technology has reshaped the way of communication as well as changed social and individual behavior. Fishbeins multi-attribute model is applicable to compute the numeric value of the attitude. Thus this model is applicable to measure customer attitude towards various benefits/services provided by the mobile phone operators -Grameenphone and Banglalink in Dhaka City.

\section{LITERATURE REVIEW}

Liu (2002) found that the choice of a cellular phone is characterized by two attitudes: attitude towards the mobile phone brand on one hand and attitude towards the network on the other.

Seth et al (2008) analyzed that there is relative importance of service quality attributes and showed that responsiveness is the most important dimension followed by reliability, customer perceived network quality, assurance, convenience, empathy and tangibles. 
Samuvel (2002) observed that most of the respondents consider size, quality, price, instrument servicing are an important factors for selecting the handset while majority of the respondents are satisfied over the payment system, quality of services, coverage area and the process of attending the complaints regarding their mobile service provider.

Nandhini (2001) examined that attitude of the respondents using cell phones was not influenced by either education or occupation and income.

Kalpana and Chinnadurai (2006) found that advertisement play a dominant role in influencing the customers but most of the customers are of opinion that promotional strategies of cellular companies are more sale oriented rather than customer oriented.

Haque et al (2007) suggested that price, service quality, product quality \& availability, and promotional offer play a main role during the time to choose telecommunication service provider.

The "Information Age" has arrived, and institutions and individuals everywhere are striving to understand and cope with it. The technologies are now being used operationally to disseminate information to more remote areas. Telecommunication operators are done this job very efficiently. Agricultural sector can also be facilities through these technologies and mobile telephone can be the most effective tool. In Bangladesh a large majority of the population have access to mobile phones (Islam \& Grönlund, 2008).

Other study was conducted on Consumer Perception \& Attitude toward Mobile Communication. This paper investigate the demand of the consumer from the telecommunication service providers, their reaction and consumption behavior. A survey was conducted to understand consumer attitude toward mobile communication \& factor that could contribute to adoption \& success of this sector (Masud \& Gupta, 2003).

Aircraft's current research examined technological changes in mobile networks and innovative attributes of Mobile Internet. It has advanced the theoretical framework of innovation in service to develop a customer centric analysis of embanking value proposition. His article goes on to discuss critical factors in the diffusion of embanking and explores reasons of failure and further prospects of success (Ayadi Achraf: "Value creation in mobile banking", 24 Aug 2005).

Above studies will be helpful to find out the variables. This study is able to explore the users' attitude towards telecommunication operators- (Grameenphone and Banglalink).

\section{PROBLEM STATEMENT}

The research paper aims to find out the real scenario of the benefits (salient beliefs) provided by different telecommunication operators for individual users and their belief and evaluation of those benefits. Here the consideration mainly on the "Users' Attitude towards Telecommunication Operators in Dhaka city"

\section{OBJECTIVES}

a. To find out demographic profiles that influence users' attitude;

b. To find out customers' attitude be more favorable to a specific operator's benefits;

c. To make suggestions be made on the basis of findings; 


\section{Type of research}

\section{RESEARCH METHODOLOGY}

The study is descriptive in nature. This study is descriptive because it describes the characteristics of population in terms of factors that influence consumer attitude mainly. A descriptive survey has been selected because it provides an accurate portrayal or account of the characteristics of behavior, opinions, abilities, beliefs, and knowledge of a particular individual, situation or group.

\section{Sources of data}

The present study is based on both primary and secondary data collection. Primary data is collected directly from the respondents in Dhaka city. The secondary data for the study is collected from different sources such as recent M.Phil and PhD thesis papers, internship reports, telecom websites, technical and Trade journal, articles, news paper, magazines, internet, periodicals, books, reports, publications of associations related to mobile phone service users etc., which are relevant to the subject matter.

\section{The instruments}

The research put the relevant data in the MS word extracted from the respondents for frequency distribution. The researcher then analyze the data using the statistical software namely Statistical Package for Social Science (SPSS) for correlation.

\section{Measurement and Scaling Technique}

In order to collect the descriptive data, nominal, interval, and ratio scales have been used. The Likert scale has been selected because they take less time, and easy to answer.

\section{Questionnaire design and pretesting}

This research adopts with close-ended questionnaire. Based on the review of literature and objectives of a preliminary draft of questionnaire has been developed and pretested and primary opinion of 30 respondents has been taken. In order to minimize any error or bias, all the three methods of pre-testing namely planned field survey, personal interviews (face to face), and expert panel have been used. Sixty four salient beliefs were identified but respondents are aware about eighteen salient beliefs only. Those are network facility, SMS services, $3 \mathrm{~g}$ services, internet modem, sports news, health line, face book services, call block, F\& F services, Balance transfer, conference call, emergency balance, ring tone, internet services, promotional offer, welcome tune, availability of services and SMS alert.

\subsection{Research Question}

1. Can demographic profiles that influence users' attitude?

2. Can customers' attitude be more favorable to a specific operator's benefits?

3. Can suggestions be made on the basis of findings?

\section{Sampling Design Populations}

The studied population consists of current individual consumers (not corporate) of Grameephone \& Banglalink in Dhaka city. Though the total number of mobile telecom subscribers are 150.945 million people (BTRC, July 2018). There is no available list of the customers of the mobile telecom industry of Bangladesh. The industry consists of both prepaid and postpaid mobile users with much diversity due to their varied age, sex, income, education, religion occupational qualifications etc. Population of the study was defined here in terms of elements and unit. Elements are all consumers of Grameenphone \& Banglalink in Dhaka city. Unit is each individual consumer of mobile phone users within the population. Elements: 
Elements are male and female who are SSC, HSC, Graduation, and Post Graduation level consumers of Grameenphone and Banglalink. Sampling unit is each individual consumer of mobile phone users (Grameenphone and Banglalink). Extent:The research extent is Dhaka City. Sampling Frame: Sampling frame includes commercial phone list provided by yellow book and business directory.

\section{Sampling Technique}

Cluster sampling method has been followed for the study by education (SSC, HSC, Graduation and Post Graduation). Each cluster contains various types of characteristics. Multi stage sampling design has been followed. In the first stage two geographic areas have been selected those are Dhaka North and South City Corporation. During stage two few intermediate college, graduate and post graduate educational institutions and the adjacent areas of those institutions have been targeted and in the final stage educational levels of the respondents have been selected. This sampling method have been used for four reasons, firstly, the consumers are scattered across not only the Dhaka City but also the country. Secondly, there is no available list or database on the customers; it is difficult to collect the data of customers of the mobile telecom operators in Dhaka City.

\section{Sample Size}

Limited data on the total population (cost and time constraints) a convenient sample size of three hundred and sixty(360) unbiased and representative sample respondents from various locations of Dhaka North and Dhaka South City Corporation have been selected.

\section{Fieldwork or Data Collection}

During the phase of marketing research process, primary data have been collected by means of self -administered and structured survey. The research 1) ensured voluntary (not forced) participation of the respondents, 2) assured the confidentiality and security of the respondents personal and private information, 3) would be carried out honestly, transparently, and objectively, without intruding or harming or adversely affecting the respondents, 4) told

The research did not 1) sell and not influence opinions of the respondents, 2) mislead or pressurize a respondent when asking them to take part, 3) eat or smoke in front of the respondents, 4) make any comments on the respondent's answer and 5) offer any comments or opinion of his own.

\section{Data Preparation and Data Analysis}

The study has been gone through quantitative analysis. As a part of quantitative analysis the popular statistical tools such as frequency distribution and correlation analysis has been utilized to reach to the objectives.

\section{Reliability and Validity}

Reliability of this study has also been improved by 1) adopting the findings of the previous studies to construct the questionnaire items and 2) pretesting the questionnaire, removing confusing words and improving their clarity of the questions items, free from collector bias.

Validity: Questions were based on information gathered during the literature review to ensure that they were representative to provide the data. Content validity has been further ensured by consistency in administering the questionnaires. All questionnaires were distributed to subjects by the researcher personally. The questions were formulated in simple language for clarity and ease of understanding. Clear instructions were given to the subjects. All the subjects 
completed the questionnaires in the presence of the researcher. This was done to prevent subjects from giving questionnaires to other people to complete on their behalf.

\section{Statistical Analysis}

For the present study frequency distribution and correlation have been used to explain the demographic data, attitudinal data and Fishbeins multi attribute model has been used to compute the numeric value of the attitude for comparing the two brands those are Grameenphone and Banglalink.

\section{Ages of the respondents}

\section{RESULT AND DISCUSSIONS}

Out of 360 , the highest number of respondents 51\%, $71 \%, 47 \%$ \& $60 \%$ are Banglalink users and their educational qualifications are SSC, HSC, Graduation \& Post Graduation and their ages are below 25 years \& $25-34$ years respectively.

On the other hand the highest number of Grameenphone users is $56 \%, 60 \%, 56 \% \& 53 \%$ and their ages are below 25 years \& 25-34 years whose educational qualifications are SSC, HSC, Graduation and post Graduation.

The lowest number of respondents $07 \%, 04 \%, 00 \%$ \& $00 \%$ are Grameenphone users whose educational qualifications are SSC, HSC, Graduation and Post Graduation \& their ages are more than 60 years, $45-60$ years .

On the other hand the lowest number of respondents $00 \%, 00 \%, 00 \%$ and $02 \%$ are Banglalink users whose educational qualifications are SSC, HSC Graduation and Post Graduation whose ages are more than 60 years and below 25 years respectively.

There is perfect positive correlation in the ages of Grameenphone \& Banglalink users at SSC level. There is perfect positive correlation in the ages of Grameenphone \& Banglalink users at HSC level. There is perfect positive correlation in the ages of Grameenphone \& Banglalink users at Graduation level. There is perfect positive correlation in the ages of Grameenphone \& Banglalink users at Post Graduation level.

\section{Gender of the respondents}

Out of 360 respondents $73 \%$ are male and their educational qualification is post graduation and $56 \%$ female and their educational qualification is HSC are from Banglalink users.

Otherwise, 67\% respondents are male and their educational qualification is post graduation and $67 \%$ are female and their educational qualification is HSC are from Grameenphone users.

The lowest number of respondents $33 \%$ is Grameenphone male users whose educational qualification is HSC and 33 female who are post graduate.

On the other hand the lowest numbers of respondents $44 \%$ are Banglalink male users whose educational qualifications are HSC and $27 \%$ are female respondents who are post graduate.

There is perfect positive correlation in the gender (male) of Grameenphone \& Banglalink users. There is perfect positive correlation in the gender (female) of Grameenphone \& Banglalink users. 


\section{Location of the respondents}

$50 \%$ respondents are from Dhaka North City Corporation and the other $50 \%$ respondents are from Dhaka South City Corporation of Grameenphone users. On the other hand 50\% respondents are from Dhaka North City Corporation and the other 50\% respondents are from Dhaka South City Corporation of Banglalink users.

\section{Education of the respondents}

Among the respondents 25\% are SSC, $25 \%$ are HSC, $25 \%$ are Graduate \& 25\% are Post Graduate level educated of Grameenphone users. Among the respondents 25\% are SSC, 25\% are HSC, 25\% are Graduate \& 25\% are Post Graduate level educated of Banglalink users.

\section{Income of the respondents}

The largest number $42 \%$ respondents' income level is $20000-30000$ Tk. Who are graduate and the lowest number $00 \%$ of respondents whose monthly income is less than 10000 taka and their educational level is graduation \& post graduation of Grameenphone users.

On the other hand, $44 \%$ respondents' income level is $20000-30000$ taka who is HSC level educated and only $02 \%$ respondents' income level is less than 10000 taka who is post graduate of Banglalink users.

There is moderate degree of positive correlation in the income level of Grameenphone \& Banglalink users at SSC level. There is moderate degree of positive correlation in the income level of Grameenphone \& Banglalink users at HSC level. There is moderate degree of positive correlation in the income level of Grameenphone \& Banglalink users at Graduation level. There is moderate degree of positive correlation in the income level of Grameenphone \& Banglalink users' at Post Graduation level

\section{Occupation of the respondents}

The largest numbers of respondents $69 \%$ are student (HSC) and the lowest number of respondents $07 \%$ are retired of Grameenphone users. On the other hand, the largest numbers of respondents $69 \%$ are student (HSC) and the lowest number of respondents $07 \%$ are businessmen and retired persons \& their educational qualifications are HSC, Graduation \& Post Graduation level of Banglalink users. There is higher degree of positive correlation in the occupation of Grameenphone \& Banglalink users at SSC level. There is higher degree of positive correlation in the occupation of Grameenphone \& Banglalink users at HSC level. There is perfect positive correlation in the occupation of Grameenphone \& Banglalink users at Graduation level. There is higher degree of positive correlation in the occupation of Grameenphone \& Banglalink users at Post Graduation level.

\section{Religion of the respondents}

Among the largest numbers of respondents $100 \%$ are Muslim (post graduate) and the lowest number of respondents $00 \%$ are others \& their educational qualifications are SSC \& Post Graduate level respectively of Grameenphone users. On the other hand, the largest number of respondents $98 \%$ are Muslim (post graduate) and the lowest number of respondents $00 \%$ are others \& their educational qualifications are Post Graduation level of Banglalink users.

There is perfect positive correlation in the religion of Grameenphone \& Banglalink users' at SSC level. There is perfect positive correlation in the religion of Grameenphone \& Banglalink users at HSC level. There is higher degree of positive correlation in the religion of Grameenphone \& 
Banglalink users' at Graduation level. There is higher degree of positive correlation in the religion of Grameenphone \& Banglalink users' at Post Graduation level.

\section{Attitude of Grameenphone \& Banglalink users}

Fishbein's multi attribute model can be expressed in equation (Robertson, 1984) as:

$$
\begin{gathered}
\mathrm{n} \\
\mathrm{A} 0=\sum \underset{\mathrm{i}=1}{\text { biei }}
\end{gathered}
$$

$\mathrm{Ao}=$ the person's overall attitude toward the object.

$\mathrm{bi}=$ the strength of his or her belief that the object is related to attribute.

ei $=$ His or her evaluation or integrity of feeling of the goodness or badness of attribute.

$\mathrm{n}=$ the number of salient beliefs about the object.

Model Components:

Belief Strength (bi)

\section{Belief strength is the perceived probability of association between an object and its relevant attributes. \\ Belief Evaluation (ei) \\ Belief evaluation reflects how favorably the consumer perceives the attributes.}

The users' of Grameenphone have greater positive attitude rather than the users' of Banglalink. So, the Fishbein's Multi Attribute Model is workable.

There is moderate degree of positive correlation in the attitude of Grameenphone \& Banglalink users at SSC level. There is higher degree of positive correlation in the attitude of Grameenphone \& Banglalink users at HSC level. There is moderate degree of positive correlation in the attitude of Grameenphone \& Banglalink users at Graduation level. There is moderate degree of positive correlation in the attitude of Grameenphone \& Banglalink users at Graduation level.

\section{CONCLUSION}

People in Bangladesh are becoming busy day by day and more professional than previous. They need to share more information to each other. Demography has changed due to the era of globalization. Today consumers are more learned, demanding and well informed than previous. In Bangladesh mobile phone has been introduced in 1993. It has become a very popular communication medium because business people, professional persons, even students are using this products intensively for their personal and occupational purposes. Thus it may also be used as an alternative medium of communication and transaction like introducing mobile transactions, m-commerce and mobile banking. It is hoped that the academic proponents and concerned professionals would accept the study outcomes and its implications for the government, business organizations and the mobile phone operators because this study finds demographic profiles of consumers that indicates attitude.

\section{SUGGESTIONS}

Area of the study is Dhaka only. As price is the second most important factor to the consumer so the operators may reduce their service prices and can improve network facility. The study concentrated on the personal consumer. It did not include corporate customers. Another research could be done on the corporate consumers. 


\section{References}

Ahmed, S. M. Sohel, and Rayhan Johir Shah. (2012), “Customers' attitude towards agro based benefits provided by the telecommunication operators in Bangladesh " European Journal of Business and Management Vol 4, No.1, 2012l. - II, pp. 70-83

Al-Ashban, A.A. \& Burney, M.A. (2001), "Customer adoption of tele-banking technology: the case of Saudi Arabia”, International Journal of Bank Marketing, 19 (5), 191-200.

Barnes, S.J., Corbitt, B. (2003), “Mobile banking: concept and potential”, International Journal of Mobile Communications, 1 (3), 273-288.

Black, N. J., Lockett, A., Ennew, C., Winklhofer, H. \& McKechnie, S. (2002), “Modelling consumer choice of distribution channels: an illustration from financial services”, International Journal of Bank Marketing, 20 (4), 161 173.

Brent C. Miller (1975), "International Patterns of Consumer Behavior”, In Advance Consumer Research Volume 02 , eds. Mary Jane Schlinger, Association for Consumer Research, pp. 93-103

Guriting, P. \& Ndubisi, N.O. (2006), "Borneo online banking: Evaluating customer perceptions and behavioral intention", Management Research News, 29(1/2), 6-15.

Hayat Muhammad Aslam (2009), "Mobile payments: Will Colombo keep its leadership in South Asia?", http://sundaytimes.lk/090712/FinancialTimes/ft323.html [accessed 30 April 2010]

Hing, Ja Leu (2002), “Service Quality, Customer Satisfaction, and Behavior Intension: Evidence from China's Telecommunication Industry", International Conference on e- Commerce and e- Government, pp275-281.

ITU (1999), World Telecommunication Report: Mobile Cellular World Telecommunication Indicators, International Telecommunication Union.

Juan Tang; Liu Li; Yao Shan-Ji, “ A Study of the Relationship between the Values and Customer Decision- Making style of Telecommunications services of University Students," International Conference on, pp260-265, 2009 International Conference on Management of e-commerce and e-Government, 2009.

Karjaluoto, H., Mattila, M. \& Pento, T. (2002), "Factors underlying attitude formation towards online banking in Finland”, International Journal of Bank Marketing, 20 (6), 261-272.

Kotler, Phlip and Armstrong, Gray, (1999), “Marketing Management.” Pearson Education, Inc. pp 189-198.

Mas, I. (2008), "Realizing the Potential of Branchless Banking: Challenges Ahead”, In: Focus Note 50. Consultancy Group to Assist the Poor (CGAP), Washington, D.C.

Mattila, M. (2003), "Factors affecting the adoption of mobile banking services", Journal of Internet Banking and Commerce, 8 (1). 101-119

Mattila, M., Karjaluoto, H. \& Pento, T. (2003), “Internet banking adoption among mature customers: early majority of laggards?”, Journal of Services Marketing, 17(5), 514-528.

Moinuddin, Md. And Uddin, (1994), Consumer Brand Choice Behavior for Motor Cycle”.Dhaka University Journal of Business Studies Volume- $X V$, p 215.

Moinuddin, Md. Kamal, (1992), “Consumers Brand Choice Behavior for Television,” Dhaka University Journel of Business Studies Volume-XIII, p.27-36.

Morawczynski, O. \& Miscione, G. (2008). “Exploring Trust in Mobile Banking Transactions: The Case Of M-Pesa In Kenya”, Social Dimensions of Information and Communication Technology Policy, pp 287-298

Owens, John \& Anna, B. (2006), “Catching the Technology Wave: Mobile Phone Banking and Text-A-Payment in the Philippines", http://www.chemonics.com/projects/content/GCash.pdf [accessed 13 Jun 2010].

Pousttchi, Key \& Schurig, Martin (2007), “Assessment of Today’s Mobile Banking Applications from the View of Customer Requirements”, http://mpra.ub.uni-muenchen.de/2913/ [accessed 10 Oct 2010]

Rao, G. R. \& Prathima, K. (2003), “Online banking in India”, Mondaq Business Briefing, 11 April, 2003.

Robertson, S. Thomas, Zielinski, John and Ward, Scott (1994), “Consumer Behavior”, 6th ed., (United States of America: Prentic Hall, Inc.1994).

Saroja Subrahmanyan, J. Tomas Gomez-arias, (2008) "Integrated Approach to Understanding Consumer Behavior at Bottom of Pyramid", Journal of Consumer Marketing, Vol. 25 Iss: 7, pp.402-412. 
Schiffman, Leon G. and Kanur, Leslile; Consumer Behavior, 5th ed., (United States of America:Prentic Hall, Inc. 1994).

Star (2011), the Daily Star, an English Daily (Dhaka), 09th February.

Wang, Xingping Zhang, "A Study on Factors Affecting Customer Equity of Telecommunication Enterprises," Management of e- Commerce and e-government, International conference on, pp.270-273, 2010 International Conference on Management of e-Commerce and e-Government,2010. (Dated, 01.08.2018)

www.thedaily kalerkantha.com dated February 13, 2016.

www.thedailyprothomalo.com,01.11.2016.

www.btrc.gov.bd

www.grameenphone.com

www.banglalink.com.bd

\section{APPENDIX}

Table: 1. Age of Grameenphone users

\begin{tabular}{|l|l|l|l|l|l|l|l|l|}
\hline Age(Years) & \multicolumn{2}{|c|}{ SSC } & \multicolumn{2}{c|}{ HSC } & \multicolumn{2}{c|}{ Graduation } & \multicolumn{2}{c|}{ Post graduation } \\
\hline Below 25 & 25 & $56 \%$ & 27 & $60 \%$ & 10 & $22 \%$ & 03 & $07 \%$ \\
\hline 25-34 Years & 07 & $16 \%$ & 11 & $24 \%$ & 25 & $56 \%$ & 24 & $53 \%$ \\
\hline 35- 44 years & 04 & $09 \%$ & 03 & $07 \%$ & 04 & $09 \%$ & 12 & $27 \%$ \\
\hline 45-60 Years & 06 & $13 \%$ & 02 & $04 \%$ & 06 & $13 \%$ & 06 & $13 \%$ \\
\hline More than 60 & 03 & $07 \%$ & 02 & $04 \%$ & 00 & $00 \%$ & 00 & $00 \%$ \\
\hline
\end{tabular}

Table.2. Age of Banglalink Users

\begin{tabular}{|l|c|c|c|c|c|c|c|c|}
\hline \multirow{2}{*}{ Age (Years) } & \multicolumn{2}{|c|}{ SSC } & \multicolumn{2}{c|}{ HSC } & \multicolumn{2}{c|}{ Graduation } & \multicolumn{2}{c|}{ Post graduation } \\
\cline { 2 - 9 } & No. & $\%$ & No. & $\%$ & No. & $\%$ & No. & $\%$ \\
\hline Below25 & 23 & $51 \%$ & 32 & $71 \%$ & 15 & $33 \%$ & 00 & $00 \%$ \\
\hline $25-34$ Years & 13 & $29 \%$ & 07 & $16 \%$ & 21 & $47 \%$ & 27 & $60 \%$ \\
\hline $35-44$ Years & 05 & $11 \%$ & 04 & $09 \%$ & 08 & $18 \%$ & 14 & $31 \%$ \\
\hline $45-60$ Years & 04 & $09 \%$ & 02 & $04 \%$ & 01 & $02 \%$ & 03 & $07 \%$ \\
\hline Above 0Years & 00 & $00 \%$ & 00 & $00 \%$ & 00 & $00 \%$ & 01 & $02 \%$ \\
\hline
\end{tabular}

Test 1. Evaluation of r: Ages at SSC level

Correlations

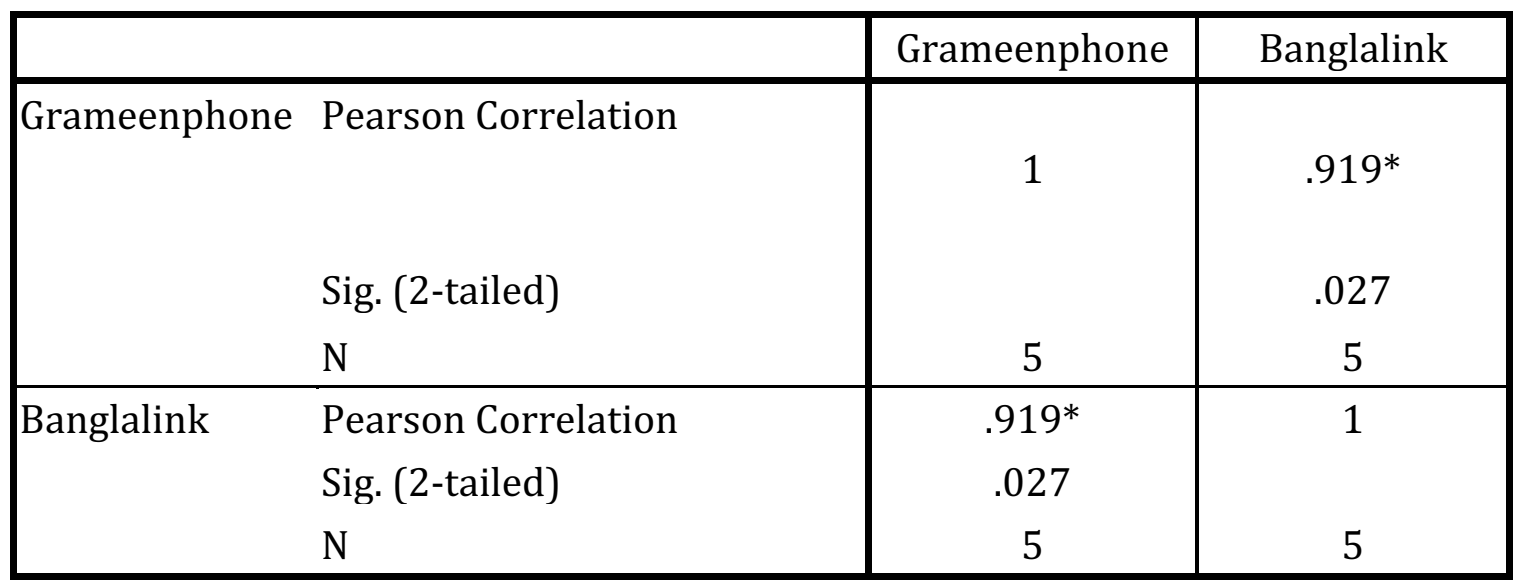

*. Correlation is significant at the 0.05 level (2-tailed). 


\section{Correlations}

Test 2.Evaluation of $r$ : Ages at HSC level

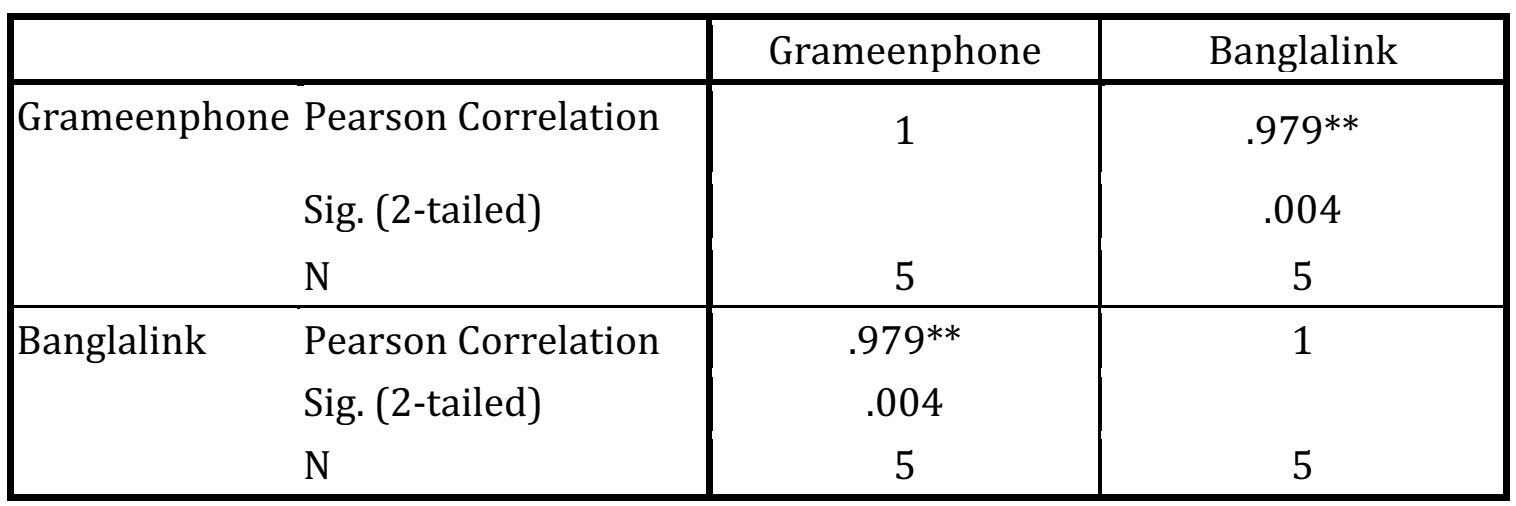

**. Correlation is significant at the 0.01 level (2-tailed).

\section{Correlations}

Test 3. Evaluation of r: Ages at Graduation level

\begin{tabular}{|ll|c|c|}
\hline & & Grameenphone & Banglalink \\
\hline Grameenphone & Pearson Correlation & 1 & $.884^{*}$ \\
& Sig. (2-tailed) & & .046 \\
& $\mathrm{~N}$ & 5 & 5 \\
\hline Banglalink & Pearson Correlation & $.884^{*}$ & 1 \\
& Sig. (2-tailed) & .046 & 5 \\
& $\mathrm{~N}$ & 5 & 5 \\
\hline
\end{tabular}

*. Correlation is significant at the 0.05 level (2-tailed).

\section{Test 4. Evaluation of r: Ages at Post Graduation level}

\section{Correlations}

\begin{tabular}{|ll|c|c|}
\hline & Grameenphone & Banglalink \\
\hline Grameenphone & Pearson Correlation & 1 & $.982^{* *}$ \\
& Sig. (2-tailed) & & .003 \\
& $\mathrm{~N}$ & 5 & 5 \\
\hline Banglalink & Pearson Correlation & $.982^{* *}$ & 1 \\
& Sig. (2-tailed) & .003 & 5 \\
& $\mathrm{~N}$ & 5 & \\
\hline
\end{tabular}

**. Correlation is significant at the 0.01 level (2-tailed). 
Table: 3. Gender of Grameenphone

\begin{tabular}{|l|c|c|c|c|}
\hline \multirow{2}{*}{} & \multicolumn{3}{|c|}{ Male } & \multicolumn{2}{c|}{ Female } \\
\cline { 2 - 5 } & No. & $\%$ & No. & $\%$ \\
\hline SSC & 16 & $36 \%$ & 29 & $64 \%$ \\
\hline HSC & 15 & $33 \%$ & 30 & $67 \%$ \\
\hline Graduation & 16 & $36 \%$ & 29 & $64 \%$ \\
\hline Post Graduation & 30 & $67 \%$ & 15 & $33 \%$ \\
\hline
\end{tabular}

Table: 4. Gender of Banglalink

\begin{tabular}{|l|c|c|c|c|}
\hline \multirow{2}{*}{} & \multicolumn{3}{|c|}{ Male } & \multicolumn{2}{c|}{ Female } \\
\cline { 2 - 5 } & No. & $\%$ & No & $\%$ \\
\hline SSC & 24 & $53 \%$ & 21 & $47 \%$ \\
\hline HSC & 20 & $44 \%$ & 25 & $56 \%$ \\
\hline Graduation & 21 & $47 \%$ & 24 & $53 \%$ \\
\hline Post Graduation & 33 & $73 \%$ & 12 & $27 \%$ \\
\hline
\end{tabular}

Test 5. Evaluation of $r$ of gender that is male

Correlations

\begin{tabular}{|ll|c|c|}
\hline & Grameenphone & Banglalink \\
\hline Grameenphone & Pearson Correlation & 1 & $.969^{*}$ \\
& Sig. (2-tailed) & & .031 \\
& $\mathrm{~N}$ & 4 & 4 \\
\hline Banglalink & Pearson Correlation & $.969^{*}$ & 1 \\
& Sig. (2-tailed) & .031 & 4 \\
& $\mathrm{~N}$ & 4 & \\
\hline
\end{tabular}

*. Correlation is significant at the 0.05 level (2-tailed).

Correlations

6. Evaluation of $r$ of gender that is female

\begin{tabular}{|c|c|c|c|}
\hline & Grameenphone & Banglalink \\
\hline \multirow[t]{3}{*}{ Grameenphone } & Pearson Correlation & 1 & $.969^{*}$ \\
\hline & Sig. (2-tailed) & & .031 \\
\hline & $\mathrm{N}$ & 4 & 4 \\
\hline \multirow[t]{3}{*}{ Banglalink } & Pearson Correlation & $.969 *$ & 1 \\
\hline & Sig. (2-tailed) & .031 & \\
\hline & $\mathrm{N}$ & 4 & 4 \\
\hline
\end{tabular}

*. Correlation is significant at the 0.05 level (2-tailed). 
Table: 5. Location of Grameenphone \& Banglalink Users

\begin{tabular}{|l|c|c|c|c|c|c|}
\hline Location & \multirow{2}{*}{ No. } & $\%$ & \multicolumn{2}{|c|}{ Grameenphone } & \multicolumn{2}{|c|}{ Banglalink } \\
\cline { 4 - 8 } & & & No. & $\%$ & No. & $\%$ \\
\hline Dhaka North City Corporation & 180 & $50 \%$ & 90 & $50 \%$ & 90 & $50 \%$ \\
\hline Dhaka South City Corporation & 180 & $50 \%$ & 90 & $50 \%$ & 90 & $50 \%$ \\
\hline
\end{tabular}

Table: 6. Education of Grameenphone Users

\begin{tabular}{|l|c|c|}
\hline & No. & $\%$ \\
\hline SSC & 45 & $25 \%$ \\
\hline HSC & 45 & $25 \%$ \\
\hline Graduation & 45 & $25 \%$ \\
\hline Post Graduation & 45 & $25 \%$ \\
\hline
\end{tabular}

Table: 7. Education of Banglalink Users

\begin{tabular}{|l|c|c|}
\hline & No. & $\%$ \\
\hline SSC & 45 & $25 \%$ \\
\hline HSC & 45 & $25 \%$ \\
\hline Graduation & 45 & $25 \%$ \\
\hline
\end{tabular}

Table: 8. Monthly Income of Grmeenphone Users

\begin{tabular}{|l|c|c|c|c|c|c|c|c|}
\hline \multirow{2}{*}{ Monthly Income } & \multicolumn{2}{|c|}{ SSC } & \multicolumn{2}{|c|}{ HSC } & \multicolumn{2}{c|}{ Graduation } & \multicolumn{2}{c|}{ PostGraduation } \\
\hline & No. & $\%$ & No. & $\%$ & No. & $\%$ & No. & $\%$ \\
\hline$<10000 \mathrm{Tk}$ & 02 & $04 \%$ & 07 & $16 \%$ & 00 & $00 \%$ & 00 & $00 \%$ \\
\hline $10000-20000 \mathrm{Tk}$ & 08 & $18 \%$ & 06 & $13 \%$ & 10 & $22 \%$ & 04 & $09 \%$ \\
\hline 20000-30000Tk & 15 & $33 \%$ & 14 & $31 \%$ & 19 & $42 \%$ & 15 & $33 \%$ \\
\hline 30000-50000Tk & 18 & $40 \%$ & 08 & $18 \%$ & 05 & $11 \%$ & 16 & $36 \%$ \\
\hline $50000-80000 \mathrm{Tk}$ & 01 & $02 \%$ & 09 & $20 \%$ & 06 & $13 \%$ & 05 & $11 \%$ \\
\hline Above 80000Tk & 01 & $02 \%$ & 01 & $02 \%$ & 05 & $11 \%$ & 05 & $11 \%$ \\
\hline
\end{tabular}


Table: 9.Monthly Income of Banglalink Users

\begin{tabular}{|l|c|c|c|c|c|c|c|c|}
\hline \multirow{2}{*}{ Income(TK) } & \multicolumn{2}{|c|}{ SSC } & \multicolumn{2}{|c|}{ HSC } & \multicolumn{2}{c|}{ Graduation } & \multicolumn{2}{c|}{ Post Graduation } \\
\hline & No. & $\%$ & No. & $\%$ & No. & $\%$ & No. & $\%$ \\
\hline$<10000$ & 02 & $04 \%$ & 03 & $07 \%$ & 05 & $11 \%$ & 01 & $02 \%$ \\
\hline $10000-20000$ & 12 & $27 \%$ & 06 & $13 \%$ & 08 & $18 \%$ & 09 & $20 \%$ \\
\hline $20000-30000$ & 18 & $40 \%$ & 20 & $44 \%$ & 16 & $36 \%$ & 13 & $29 \%$ \\
\hline $30000-50000$ & 07 & $16 \%$ & 11 & $24 \%$ & 09 & $20 \%$ & 09 & $20 \%$ \\
\hline $50000-80000$ & 04 & $09 \%$ & 03 & $07 \%$ & 04 & $09 \%$ & 08 & $18 \%$ \\
\hline Above 80000 & 02 & $04 \%$ & 02 & $04 \%$ & 03 & $07 \%$ & 05 & $11 \%$ \\
\hline
\end{tabular}

Test 7. Evaluation of $r$ of income at SSC level

Correlations

\begin{tabular}{|c|c|c|c|}
\hline & & Grameenphone & Banglalink \\
\hline Grameenphone & $\begin{array}{l}\text { Pearson Correlation } \\
\text { Sig. (2-tailed) } \\
\mathrm{N}\end{array}$ & $\begin{array}{l}1 \\
6\end{array}$ & $\begin{array}{c}.687 \\
.131 \\
6\end{array}$ \\
\hline Banglalink & $\begin{array}{l}\text { Pearson Correlation } \\
\text { Sig. (2-tailed) } \\
\mathrm{N}\end{array}$ & $\begin{array}{c}.687 \\
.131 \\
6\end{array}$ & $\begin{array}{l}1 \\
6\end{array}$ \\
\hline
\end{tabular}

Test 8. Evaluation of $r$ of income at HSC level

Correlations

\begin{tabular}{|ll|c|c|}
\hline & Grameenphone & Banglalink \\
\hline Grameenphone & Pearson Correlation & 1 & .792 \\
& Sig. (2-tailed) & & .060 \\
& $\mathrm{~N}$ & 6 & 6 \\
\hline Banglalink & Pearson Correlation & .792 & 1 \\
& Sig. (2-tailed) & .060 & 6 \\
& $\mathrm{~N}$ & 6 & \\
\hline
\end{tabular}




\section{Correlation}

Test 9. Evaluation of $r$ of income at Graduation level

\begin{tabular}{|ll|c|c|}
\hline & & Grameenphone & Banglalink \\
\hline Grameenphone & Pearson Correlation & 1 & $.827^{*}$ \\
& Sig. (2-tailed) & & .042 \\
& $\mathrm{~N}$ & 6 & 6 \\
\hline Banglalink & Pearson Correlation & $.827^{*}$ & 1 \\
& Sig. (2-tailed) & .042 & 6 \\
& $\mathrm{~N}$ & 6 & \\
\hline
\end{tabular}

*. Correlation is significant at the 0.05 level (2-tailed).

Test 10. Evaluation of $r$ of income at Post Graduation level

\section{Correlations}

\begin{tabular}{|ll|c|c|}
\hline & & Grameenphone & Banglalink \\
\hline Grameenphone & Pearson Correlation & 1 & .775 \\
& Sig. (2-tailed) & & .070 \\
& $\mathrm{~N}$ & 6 & 6 \\
\hline Banglalink & Pearson Correlation & .775 & 1 \\
& Sig. (2-tailed) & .070 & 6 \\
& $\mathrm{~N}$ & 6 & \\
\hline
\end{tabular}

Table: 10. Occupation of Banglalink Users

\begin{tabular}{|l|c|c|c|c|c|c|c|c|}
\hline \multirow{2}{*}{ Occupation } & \multicolumn{2}{|c|}{ SSC } & \multicolumn{2}{c|}{ HSC } & \multicolumn{2}{c|}{ Graduation } & \multicolumn{2}{c|}{ Post Graduation } \\
\cline { 2 - 9 } & No. & $\%$ & No. & $\%$ & No. & $\%$ & No. & $\%$ \\
\hline Student & 23 & $51 \%$ & 31 & $69 \%$ & 18 & $40 \%$ & 04 & $09 \%$ \\
\hline Service & 05 & $11 \%$ & 05 & $11 \%$ & 17 & $38 \%$ & 33 & $73 \%$ \\
\hline Business & 09 & $20 \%$ & 03 & $07 \%$ & 07 & $16 \%$ & 05 & $11 \%$ \\
\hline Retired & 08 & $18 \%$ & 06 & $13 \%$ & 03 & $07 \%$ & 03 & $07 \%$ \\
\hline
\end{tabular}

Table:11. Occupation of Grameenphone users

\begin{tabular}{|l|c|c|c|c|c|c|c|c|}
\hline Occupation & \multicolumn{2}{|c|}{ SSC } & \multicolumn{2}{c|}{ HSC } & \multicolumn{2}{c|}{ Graduation } & \multicolumn{2}{c|}{ Post Graduation } \\
\hline Student & 25 & $56 \%$ & 31 & $69 \%$ & 25 & $56 \%$ & 06 & $13 \%$ \\
\hline Service & 05 & $11 \%$ & 06 & $13 \%$ & 13 & $29 \%$ & 29 & $64 \%$ \\
\hline Business & 07 & $16 \%$ & 04 & $09 \%$ & 04 & $09 \%$ & 04 & $09 \%$ \\
\hline Retired & 08 & $18 \%$ & 04 & $09 \%$ & 03 & $07 \%$ & 04 & $09 \%$ \\
\hline
\end{tabular}




\section{Correlations}

Test 11. Evaluation of $r$ of occupation at SSC level

\begin{tabular}{|ll|c|c|}
\hline & & Grameenphone & Banglalink \\
\hline Grameenphone & Pearson Correlation & 1 & $.992^{* *}$ \\
& Sig. (2-tailed) & & .008 \\
& $\mathrm{~N}$ & 4 & 4 \\
\hline Banglalink & Pearson Correlation & $.992^{* *}$ & 1 \\
& Sig. (2-tailed) & .008 & 4 \\
& $\mathrm{~N}$ & 4 & \\
\hline
\end{tabular}

**. Correlation is significant at the 0.01 level (2-tailed).

\section{Correlations}

Test 12. Evaluation of $r$ of occupation at HSC level

\begin{tabular}{|c|c|c|c|}
\hline & Grameenphone & Banglalink \\
\hline \multicolumn{2}{|c|}{ Grameenphone Pearson Correlation } & 1 & $.984^{*}$ \\
\hline & Sig. (2-tailed) & & .016 \\
\hline & $\mathrm{N}$ & 4 & 4 \\
\hline \multirow[t]{3}{*}{ Banglalink } & Pearson Correlation & $.984^{*}$ & 1 \\
\hline & Sig. (2-tailed) & .016 & \\
\hline & $\mathrm{N}$ & 4 & 4 \\
\hline
\end{tabular}

*. Correlation is significant at the 0.05 level (2-tailed).

Test13. Evaluation of $r$ of occupation at Graduation level

\section{Correlations}

\begin{tabular}{|ll|c|c|}
\hline & Grameenphone & Banglalink \\
\hline Grameenphone & Pearson Correlation & 1 & .889 \\
& Sig. (2-tailed) & & .111 \\
& $\mathrm{~N}$ & 4 & 4 \\
\hline Banglalink & Pearson Correlation & .889 & 1 \\
& Sig. (2-tailed) & .111 & 4 \\
\hline
\end{tabular}




\section{Correlations}

Test 14. Evaluation of $r$ of occupation at Post Graduation level

\begin{tabular}{|ll|c|c|}
\hline & Grameenphone & Banglalink \\
\hline Grameenphone & Pearson Correlation & 1 & $.995^{* *}$ \\
& Sig. (2-tailed) & & .005 \\
& $\mathrm{~N}$ & 4 & 4 \\
\hline Banglalink & Pearson Correlation & $.995^{* *}$ & 1 \\
& Sig. (2-tailed) & .005 & 4 \\
& $\mathrm{~N}$ & 4 & \\
\hline
\end{tabular}

**. Correlation is significant at the 0.01 level (2-tailed).

Table: 12. Religion of Grameenphone Users

\begin{tabular}{|l|c|c|c|c|c|c|c|c|}
\hline \multirow{2}{*}{ Religion } & \multicolumn{2}{|c|}{ SSC } & \multicolumn{2}{|c|}{ HSC } & \multicolumn{2}{c|}{ Graduation } & \multicolumn{2}{c|}{ Post Graduation } \\
\cline { 2 - 8 } & No. & $\%$ & No. & $\%$ & No. & $\%$ & No. & $\%$ \\
\hline Muslim & 43 & $96 \%$ & 41 & $91 \%$ & 43 & $96 \%$ & 45 & $100 \%$ \\
\hline Hindu & 02 & $04 \%$ & 03 & $07 \%$ & 01 & $02 \%$ & 00 & $00 \%$ \\
\hline Other & 00 & $00 \%$ & 01 & $02 \%$ & 01 & $02 \%$ & 00 & $00 \%$ \\
\hline
\end{tabular}

Table: 13. Religion of Banglalink Users

\begin{tabular}{|l|c|c|c|c|c|c|c|c|}
\hline \multirow{2}{*}{ Religion } & \multicolumn{2}{|c|}{ SSC } & \multicolumn{2}{|c|}{ HSC } & \multicolumn{2}{c|}{ Graduation } & \multicolumn{2}{|c|}{ Post graduation } \\
\hline & No. & $\%$ & No. & $\%$ & No. & $\%$ & No. & $\%$ \\
\hline Muslim & 42 & $93 \%$ & 42 & $93 \%$ & 36 & $80 \%$ & 44 & $98 \%$ \\
\hline Hindu & 02 & $04 \%$ & 02 & $04 \%$ & 08 & $18 \%$ & 01 & $02 \%$ \\
\hline Other & 01 & $02 \%$ & 01 & $02 \%$ & 01 & $02 \%$ & 00 & $00 \%$ \\
\hline
\end{tabular}

Test 15. Evaluation of $r$ of religion at SSC level

Correlations

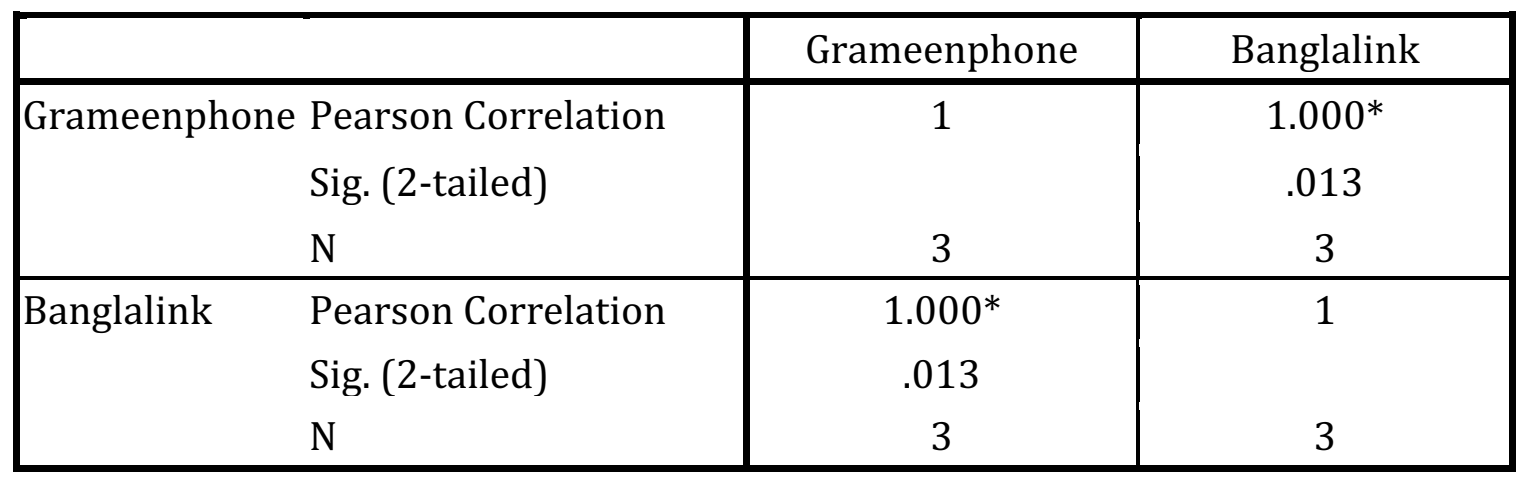

*. Correlation is significant at the 0.05 level (2-tailed). 
Correlations

Test 16. Evaluation of $r$ of religion at HSC level

\begin{tabular}{|ll|c|c|}
\hline & Grameenphone & Banglalink \\
\hline Grameenphone & Pearson Correlation & 1 & $1.000^{*}$ \\
& Sig. (2-tailed) & & .015 \\
& $\mathrm{~N}$ & 3 & 3 \\
\hline Banglalink & Pearson Correlation & $1.000^{*}$ & 1 \\
& Sig. (2-tailed) & .015 & 3 \\
& $\mathrm{~N}$ & 3 & \\
\hline
\end{tabular}

*. Correlation is significant at the 0.05 level (2-tailed).

Test 17. Evaluation of $\mathbf{r}$ of religion at Graduation level

Correlations

\begin{tabular}{|ll|c|c|}
\hline & Grameenphone & Banglalink \\
\hline Grameenphone & Pearson Correlation & 1 & .982 \\
& Sig. (2-tailed) & & .121 \\
& $\mathrm{~N}$ & 3 & 3 \\
\hline Banglalink & Pearson Correlation & .982 & 1 \\
& Sig. (2-tailed) & .121 & 3 \\
\hline
\end{tabular}

Test 18. Evaluation of $r$ of religion at Post Graduation level

\section{Correlations}

\begin{tabular}{|c|c|c|c|}
\hline & & Grameenphone & Banglalink \\
\hline \multicolumn{2}{|c|}{ Grameenphone Pearson Correlation } & 1 & $1.000^{* *}$ \\
\hline & Sig. (2-tailed) & & .000 \\
\hline & $\mathrm{N}$ & 3 & 3 \\
\hline \multirow[t]{3}{*}{ Banglalink } & Pearson Correlation & $1.000^{* *}$ & 1 \\
\hline & Sig. (2-tailed) & .000 & \\
\hline & $\mathrm{N}$ & 3 & 3 \\
\hline
\end{tabular}

**. Correlation is significant at the 0.01 level (2-tailed). 


\section{Table:15}

\section{Attitude towards Grameenphone \& Banglalink}

\begin{tabular}{|c|c|c|c|c|c|c|c|c|c|c|}
\hline \multirow{2}{*}{$\begin{array}{l}\text { Measurement } \\
\text { Salient Beliefs }\end{array}$} & \multicolumn{5}{|c|}{ Grameenphone } & \multicolumn{5}{|c|}{ Banglalink } \\
\hline & SSC & HSC & Graduation & $\begin{array}{l}\text { Post } \\
\text { Graduation }\end{array}$ & Total & SSC & HSC & Graduation & $\begin{array}{l}\text { Post } \\
\text { Graduation }\end{array}$ & Total \\
\hline Network Facility & 205 & 250 & 255 & 291 & 1001 & 329 & 153 & 185 & 169 & 836 \\
\hline SMS Services & 78 & 121 & 156 & 145 & 500 & 139 & 156 & 92 & 118 & 505 \\
\hline 3g Services & 29 & 51 & 143 & 195 & 418 & 101 & 104 & 104 & 138 & 447 \\
\hline Internet Modem & 16 & 53 & 55 & 38 & 162 & -6 & -22 & 33 & 93 & 98 \\
\hline Sports News & 2 & 8 & 94 & 79 & 183 & 15 & 9 & 16 & 78 & 118 \\
\hline Health Line & 35 & 42 & 50 & 37 & 164 & 6 & 9 & -4 & 78 & 89 \\
\hline Face book Service & 113 & 136 & 192 & 209 & 650 & 99 & 135 & 71 & 132 & 437 \\
\hline Call Block & -37 & 28 & 104 & 25 & 120 & 49 & 63 & 21 & 108 & 241 \\
\hline F\& F services & 161 & 238 & 204 & 219 & 822 & 146 & 215 & 77 & 182 & 620 \\
\hline Balance Transfer & 114 & 36 & 98 & 124 & 372 & 23 & 51 & 98 & 157 & 329 \\
\hline Conference Call & 96 & 99 & 85 & 157 & 437 & 113 & 144 & 97 & 151 & 505 \\
\hline Emergency Balance & 266 & 115 & 211 & 221 & 803 & 237 & 311 & 131 & 247 & 926 \\
\hline Ring Tone & 39 & 26 & 58 & 37 & 160 & -11 & 22 & -25 & 92 & 78 \\
\hline Internet Services & 97 & 108 & 177 & 209 & 591 & 119 & 106 & 56 & 134 & 415 \\
\hline Promotional Offer & 89 & 63 & 34 & 23 & 209 & 47 & 39 & 28 & 107 & 221 \\
\hline Welcome Tune & -49 & 32 & 35 & 65 & 83 & 19 & -21 & -10 & 73 & 61 \\
\hline Availability of Services & 46 & 111 & 136 & 79 & 372 & 34 & 63 & 38 & 151 & 286 \\
\hline SMSAlert & 56 & 34 & 134 & 49 & 273 & 54 & 52 & 31 & 78 & 215 \\
\hline ource: Field S & & & & $\Gamma$ & & & & & & 27 \\
\hline
\end{tabular}




\section{Correlations}

Test 19. Evaluation of $\mathbf{r}$ of Attitude at SSC level

\begin{tabular}{|ll|c|c|}
\hline & Grameenphone & Banglalink \\
\hline Grameenphone & Pearson Correlation & 1 & $.793^{* *}$ \\
& Sig. (2-tailed) & & .000 \\
& $\mathrm{~N}$ & 18 & 17 \\
\hline Banglalink & Pearson Correlation & $.793^{* *}$ & 1 \\
& Sig. (2-tailed) & .000 & 17 \\
& $\mathrm{~N}$ & 17 & 17 \\
\hline
\end{tabular}

**. Correlation is significant at the 0.01 level (2-tailed).

Test 20. Evaluation of $r$ of Attitude at HSC level

\section{Correlations}

\begin{tabular}{|c|c|c|c|}
\hline & Grameenphone & Banglalink \\
\hline \multicolumn{2}{|c|}{ Grameenphone Pearson Correlation } & 1 & $.689 * *$ \\
\hline & Sig. (2-tailed) & & .002 \\
\hline & $\mathrm{N}$ & 18 & 18 \\
\hline \multirow[t]{3}{*}{ Banglalink } & Pearson Correlation & $.689 * *$ & 1 \\
\hline & Sig. (2-tailed) & .002 & \\
\hline & $\mathrm{N}$ & 18 & 18 \\
\hline
\end{tabular}

**. Correlation is significant at the 0.01 level (2-tailed).

Test 21. Evaluation of $r$ of Attitude at Graduation level

\section{Correlations}

\begin{tabular}{|ll|c|c|}
\hline & Grameenphone & Banglalink \\
\hline Grameenphone & Pearson Correlation & 1 & $.779^{* *}$ \\
& Sig. (2-tailed) & & .000 \\
& $\mathrm{~N}$ & 18 & 18 \\
\hline Banglalink & Pearson Correlation & $.779^{* *}$ & 1 \\
& Sig. (2-tailed) & .000 & 18 \\
& $\mathrm{~N}$ & 18 & 18 \\
\hline
\end{tabular}

**. Correlation is significant at the 0.01 level (2-tailed). 
Test 22. Evaluation of $r$ of Attitude at Post Graduation level

\section{Correlations}

\begin{tabular}{|c|c|c|c|}
\hline & & Grameenphone & Banglalink \\
\hline \multirow[t]{3}{*}{ Grameenphone } & Pearson Correlation & 1 & $.740^{* *}$ \\
\hline & Sig. (2-tailed) & & .000 \\
\hline & $\mathrm{N}$ & 18 & 18 \\
\hline \multirow[t]{3}{*}{ Banglalink } & Pearson Correlation & $.740^{* *}$ & 1 \\
\hline & Sig. (2-tailed) & .000 & \\
\hline & $\mathrm{N}$ & 18 & 18 \\
\hline
\end{tabular}

**. Correlation is significant at the 0.01 level (2-tailed). 